\title{
More compensation in Finland for nuclear accident victims $t^{s}$,
}

\section{London}

FINLAND's Ministry of Trade and Industry is preparing an amendment to the law on nuclear accidents that will considerably increase the maximum compensation payable to victims. According to the Ministry of Justice, the maximum liability of nuclear power companies will probably be increased tenfold to Fmk 500 million (about $£ 70$ million) per station, and the maximum state liability by a factor of 2.5 to FM 1000 million. The bill has already been passed by the present parliament, but, having been introduced late in the parliament's four-year life, it will have to be resubmitted to the incoming parliament after the March general election. In the aftermath of Chernobyl, however, there seems little doubt that the bill will become law.

Although Finland escaped the worst of the first wave of Chernobyl fallout, the government's handling of the incident has been widely criticized. In Finland, the task of informing the public was left to the nuclear 'experts', in particular the head of the Institute of Radiation Protection, Ante Vuorinen, who said there was no information he could give except that radiation levels were up - but nowhere near the danger level. In fact, the radiation levels came close to the danger level only at the military base of Kajaani but the experts' attitude did not inspire public confidence. Doctors in particular complained that they had to try to cull information from the general press, which had frequently either misunderstood the little told them, or were reprinting foreign speculations.

Later studies of information flow and media coverage, made at the Universities of Helsinki and Tampere, compared the government's handling of the emergency unfavourably to the more open approach followed in neighbouring Sweden, though the Tampere study established that some nuclear experts felt it was unfair to leave the reporting of nuclear power issues in the hands of editors, most of whom openly admit to being opposed to nuclear power.

But despite this, the effect of Chernobyl on Finnish public opinion was less marked than might have been expected, the Tampere study concluded. Public opinion polls gave a level of 60 per cent opposed to nuclear power in May, compared with 33 per cent before Chernobyl. But this had fallen to 58 per cent by June and to 44 per cent by December. The time-scale, however, was significant - the accident came just as the government was about to give the go-ahead for a fifth nuclear power station in Finland, a scheme that has now been shelved.

Equally, however, post-Chernobyl de- mands that Finland should phase out the existing stations were summarily rejected. Apart from peat and 'energy woods', Finland has no domestic energy resources, and imported fossil fuels, including Soviet oil, are not only expensive but are also harmful to the country's main natural asset, the forests

From the beginning of their nuclear power programme, the Finns have been mindful of the dangers. Two of their four existing nuclear stations were purchased from Sweden and two from the Soviet Union. The latter are of VVER-type the RBMK (the type used at Chernobyl) has so far never been installed outside the Soviet Union. The Finnish VVERs, however, have a feature not found in the

Soviet prototype - a Westinghouse containment building (Finnish wits call the composite an 'Eastinghouse').

But, since Chernobyl, the main nuclear power threat has seemed, to many Finns, not their own 'Eastinghouses', but the other Soviet RBMK stations, at Ignalina and Leningrad, far nearer than Chernobyl. Finland has, of course, acceded to the new Convention on the Rapid Notification of nuclear accidents, drawn up by the International Atomic Energy Agency last October, and has also (two weeks ago) concluded a bilateral agreement on nuclear safety with the Soviet Union.

One idea now current in Finland is that this cooperation could include the construction by the Finns of containment vessels for the Ignalina and Leningrad RBMKs. The Soviet view is that containment buildings are unnecessary and could not have prevented the escape of radioactive material at Chernobyl.

Vera Rich

\section{Texas amongst early contenders in the race to subsidize the SSC}

\section{Washington}

THE Department of Energy (DoE) has sounded the starting gun and the race to play host to the Superconducting Super Collider (SSC) is under way. On 10 February, Secretary of Energy John Herrington explained how and when a site for the $\mathrm{SSC}$, which will be the largest particle accelerator ever built, will be selected. The prize for the state that wins will be construction jobs and a long-term increase in local spending.

Construction of the $\$ 4,400$ million instrument is due to begin in 1989 and to be completed in seven years. Offers of sites will first be reviewed by a panel whose members will be selected by the National

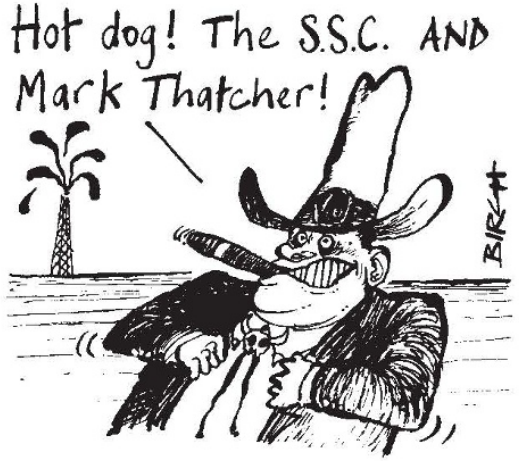

Academy of Sciences and the National Academy of Engineering. On the basis of the panel's recommendations, the DoE will select the best site by July next year, subject to later environmental and geological investigation.

One of the considerations will be the guarantees given by biduers to help contain the cost. Herrington said last week that the DoE is assuming that the chosen state will have offered to provide the land on which the collider is to be built, but the bid will probably have to contain much more than that. One candidate site is that of Fermilab in Illinois, where the existing proton accelerator could serve as an injector for the new machine, perhaps saving a few hundred million dollars. At least two other states are said to have made offers to match that saving with cash.

Texas has been interested since the project was first discussed by the HighEnergy Physics Advisory Panel early in the decade, while New York and California are among the others now interested. Overseas contributions may also help. Herrington said that he "wouldn't be surprised" if foreign contributions accounted for 25-50 per cent of the construction cost.

While the future of the SSC will rest ultimately with Congress, the DoE has not asked for new funds for the next fiscal year, beginning on 1 October, but assesses that the $\$ 35$ million needed will be reallocated from existing funds. But winning congressional approval for the projected $\$ 348$ million expenditure for the collider in fiscal year 1989 "will be a battle," according to one Senate staff member. The balance of the costs will have to be agreed by the next Congress.

The operating costs of the SSC are expected to be $\$ 270$ million a year, and will be borne by the DoE. Herrington said that the funds would not be diverted from other programmes such as those at Fermilab and the Stanford Linear Accelerator Center, but a spokesman added later that those laboratories might not be operating when the SSC is on line.

Steven Dickman 